\title{
Re-purchase intentions and virtual customer relationships on social media brand community
}

\author{
Ching-Wei Ho and Yu-Bing Wang ${ }^{*}$ (i)
}

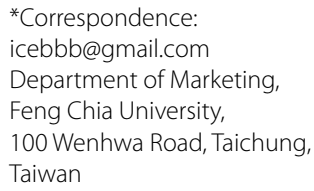

\begin{abstract}
The purpose of this study was to demonstrate how to manage digital customer relationships (i.e. relationships with the brand, the product, the company, and other fans) on social media based community (i.e. Facebook brand fan-pages) and to influence post-purchase intentions (i.e. word-of-mouth and re-purchase intentions). This study used partial least squares to test the hypotheses and analyze the data. The results of this study indicated that all these four customer-community relationships can enhance post-purchase behaviors by improving individual community participation or identification. The findings are of benefit to both academics and practitioners and this research is one of the first to demonstrate how to manage digital customer relationships on social media brand community.
\end{abstract}

Keywords: Customer-centric model of brand community, Community participation, Community identification, Repurchase intention, Word-of-mouth, Social media

\section{Background}

Over the past years, the idea of the online community occupies a mainly important space in electronic marketing research. Particularly, recently, with the increasing development and popularity of social media, the brand community operating on the social media has become extremely fashionable and can be expressed as networks of friends for social or professional interactions [1]. Social media is a tool that supports both electronic commerce and viral marketing, and enables the process of building connections to a network or social circle [2]. Therefore, for doing electronic commerce, it has been said that 2010 was the year of social media marketing, particularly in Asia. Currently, almost 90\% of Asian brands use social networks as an electronic commerce platform, and $75 \%$ of these brands have developed social networking strategies that have been in use for over 1 year [3].

Many marketers have noticed the social influence of brand community on social media and become more interested in learning about, organizing, and facilitating it (e.g. [4]). Loads of studies underlie this circumstance, including the ability of brand communities to influence members' perceptions and actions (e.g. [5]), to rapidly distribute information (e.g. [6]), to connect and collaborate with highly loyal customers (e.g. [7]), and to engage in activities (e.g. [8]). However, mainly previous works almost saw "community"

(c) $2015 \mathrm{Ho}$ and Wang. This article is distributed under the terms of the Creative Commons Attribution 4.0 International License (http://creativecommons.org/licenses/by/4.0/), which permits unrestricted use, distribution, and reproduction in any medium, provided you give appropriate credit to the original author(s) and the source, provide a link to the Creative Commons license, and indicate if changes were made. 
as a whole rather than considering as many individual members. Moving from managing the community to managing its individual members is a contemporary essential issue for conducting e-commerce management and the cutting edge of e-marketing practice. Therefore, this study is going to complete this gap through exploring the individual digital customer relationship within social media based community (i.e. Facebook brand community) and investigating the influencing effects on post-purchase intentions.

Social media has changed individual consumer behavior, for example, consumers dedicate almost one-third of their time to social networks [9], and an increasing amount of people spend time in communities. Therefore, some scholars, e.g. Kaplan and Haenlein [10] and Ouwersloot and Odekerken-Schröder [11], believed that community participation has become important to be considered. According to Royo-Vela and Casamassima [12], participation in a virtual brand community seems to influence participants' behaviors. However, the consequence of participation is usually to be discussed about the loyalty from previous studies, e.g. Casalo et al. [13] stated that participation in a virtual brand community increases consumers' loyalty. Less researches mentioned the individual's intention to repurchase as the consequence after be participating a brand community. Therefore, this study is going to consider individual's brand community participation as an influencing factor on his or her behavioral intention for post-purchase.

Simultaneously, brand communities tend to be identified on the basis of identification among their members [4]. The more individuals classify themselves in a particular community and identify themselves as members, the more likely they are to believe and buy products according to other members' suggestions [14]. Even though brand community identification is proposed to have both positive and negative consequences for consumers, many scholars still agreed that community identification leads to positive significant consequences on loyalty (e.g. [8]) and attachment (e.g. [4]). Not as much of literatures discussed the individual's intention to repurchase as the consequence of community identification. Thus, this study is going to posit individual's brand community identification as an influencing feature on his or her behavioral intention for post-purchase.

Additionally, empirical studies on Social Media brand communities and its role for behavioral intention for post-purchase to the brand is in its infancy. The current empirical study enhances the knowledge about brand community on Social Media by investigating individual community participations and individual community identification. It then hypothesizes that the more an individual participated a brand community on Social Media, the more likely he or she identifies him or her as one of the brand community members and then to exhibit post-purchase behaviors that will benefit the brand. According to Smith et al. [15], post-purchase intention can be classified into economic behavioral intentions, e.g. repurchase intention [16-19] and social behavioral intentions, e.g. word-of-mouth communication intentions [17-19].

This research begin with a brief overview of the literature concerning brand community on Social Media, and then develop the framework that describes individual digital customer relationship within Social Media brand community can contribute to community participation and identification and how post-purchase intentions are influenced by individual's participation and identification in Social Media brand community. Further, it tests the model and hypotheses using structural equation modeling (SEM) with survey 
data. Finally, this paper concludes with a discussion of marketing significance, theoretical and practical implications, and limitations for future research.

\section{Literatures and hypotheses development}

Digital customer relationships within social media community

Social networks afford companies the possibility of mapping social connections to expand relationships and spread information [20,21]. Social networks have become a significant source of information for a large number of people in the recent years [22]. Therefore, social networking has been seen as a tool that enables to build relationships or connections to a network for supporting e-marketing or viral marketing [2]. Kaplan and Haenlein ([10], p 61) define social networking media as "a group of Internet-based applications that build on the ideological and technological foundations of Web 2.0, and that allow the creation and exchange of User Generated Content". Social media communities are one of the important achievements of Web 2.0 technologies and have been welcomed by academic researchers and commercial organizations [23].

Of all the social networks, Facebook is the most popular and claims to have attracted over 751 million active monthly users (as of March 2013) since starting in February 2004 (http://www.facebook.com). In Taiwan there were over 10 million members in 2011 [24]. Facebook has become the top social networking site by number of users and volume of access or use [25]. Half of these active users log on every day. More and more companies and brand players find that it is necessary to have a brand presence on a social networking site, so Facebook has established the brand community (i.e. Facebook fan pages) where fans or consumers can interact and communicate with companies or brands by "Like" or "Comment". A brand community is defined as a group of people with a shared interest in a specific brand, creating a subculture around the brand with its own values, myths, hierarchy, rituals and vocabulary [26]. Moreover, Muniz and O'Guinn [27] defined the brand community as "a specialized, non-geographically bound community, based on a structured set of social relations among admirers of a brand" ( $\mathrm{p} 412)$.

According to Hsu [25], the Facebook brand community includes the following features: sharing company, product or service information; communicating and sharing marketing messages; expanding networks; getting feedback updates. Brand fans can share their enthusiasm about the brand on these dedicated pages and be united by their common interest in the brand $[28,29]$. Social Media brand community reflects part of the relationship with the brand [4] and expands the customer-brand relationship [27]. Consumers who become members of these Social Media brand community tend to be loyal and committed to the company and are more open to receiving information about the brand [30]. Furthermore, brand fans tend to visit the store more, generate more positive wordof-mouth, and are more emotionally attached to the brand than non-brand fans [31].

In order to understand how manage and maintain a good digital customer relationship within a brand community, customer-centric model of brand community [4] is applied in this study. According to McAlexander et al. [4], "a community is made up of its entities and the relationships among them" ( $p$ 38). Therefore, a Social Media brand community comprises entities, e.g. the brand, products, customers, the company and four relationships, such as customer-brand relationship, customer-product relationship, customer-company relationship, and customer-other customer relationship. This study 
is going to explore individual digital customer relationship within Social Media brand community through investigating these four relationships.

\section{Individual community participation}

Individuals from all over the world can freely share their comments or questions in social media communities without any limitations regarding time or place constraints [23]. Individual community participation can be discussed in terms of interacting and cooperating with community members, helping other members, participating in joint activities, acting in ways that endorse the community, and enhancing its value for themselves and others (e.g. $[8,32])$. According to previous literatures, consumer motivations to participate in a brand community are normally summarized as the following benefits: practical benefits include informational and instrumental benefits [33]. Social benefits refer to social recognition or even friendship [34]. Social enhancement derives from the customers' need to feel useful, recognized and needed in the community [35]. Entertainment benefits are derived from relaxation and fun [33]. Economic benefits refer to people joining brand communities in order to gain time savings or to take part in raffles and competitions [34]. The last but not the least is affective commitment which can be regards as a fundamental reason for brand community participation [4]. It is believed that Social Media brand community could satisfy above six main motivations through providing high-context interactions among elements of a brand community. When a customer logs onto a brand fan page to become a member and comments, shares experiences, interacts with marketers, asks questions about the brand or the product or answers comments, that member is participating in the community activities. During these interactions, meaningful experiences, useful information and other valuable resources are being shared among members, so that ties could be strengthened in such communities [36] and increase individual willingness to participate in this community. As a result, based on the above discussion, the following hypothesis is put forward:

H1 Higher levels of (a) customer-brand relationship, (b) customer-product relationship, (c) customer-company relationship, and (d) customer-other customers relationships in Social Media brand community would lead to higher levels of individual community participation.

\section{Brand community identification}

The subject of social identification and its impact on individual behavior has taken on increasing importance in customer relationship management. According to Lembke and Wilson [37], identification exists when a member feels, thinks and behaves like a member of the group, which means that the member distinguishes a group identity from a self identity. Earlier researches have found that identification was discussed to include employees of organizations (e.g. [38]), customers (e.g. [39]), members of museums (e.g. [40]), and sports fans (e.g. [41]). Recent studies begin by considering the strength of the consumer's relationship with the brand community, which can be illustrated as "brand community identification" [42]. As said by Algesheimer et al. [8], "brand community 
identification" relates to whether an individual considers himself or herself a member, namely, "belonging" to the brand community.

In line with the previous studies of Fournier et al. [43] and Muniz and Schau [5], this research considers that a closer customer/brand relationship is associated with a greater level of brand community identification. Furthermore, drawing on Algesheimer et al. [8], Pratt [44], and Dutton et al. [45], it is thought that a closer customer/product relationship is also associated with a greater level of brand community identification. On the basis of investigations by Bhattacharya et al. [40], Mael and Ashforth [46], and McAlexander et al. [4], it is believed that a closer customer/company relationship is associated with a greater level of brand community identification. Finally, in line with McAlexander et al. [4], it is supposed that closer customer/other customer relationships are associated with a greater level of brand community identification. Moreover, members' strong identification with a particular online community has been viewed as the core value that facilitates the effectiveness of the online community [8, 14, 47, 48]. As a specific type of social attachment, community identification in an online group is rather close to the sense of identification observed in traditional community groups [14]. Therefore, it could be supposed that strengthening the relationship among entities within a brand community would affect brand community identification. Based on the above discussion, the following hypothesis is put forward:

H2 Higher levels of (a) customer-brand relationship, (b) customer-product relationship, (c) customer-company relationship, and (d) customer-other customer relationships in Social Media brand community would lead to higher levels of individual community identification.

It is commonly for individual participation to classify into two different modes: passive mode (named as participation) and active mode (named as interaction) [14, 29, 49]. Prior researches suggested that even passive participation, which includes lurking, also relates to members' sense of identification [50]. Some scholars believed that active lurking enables members to better evaluate online communications and to develop a sense of identification [39, 48]. A number of recent literatures, e.g. Carlson et al. [48], Takahashi et al. [51], Thorbjornsen et al. [52], found that, like active participants, lurkers are also influenced by the community value and give priority to the value of their community by displaying some supportive member behaviors [14]. Moreover, several academic words, such as, Bergami and Bagozzi [38], Gruen et al. [53], and McWilliam [54], have suggested that if members become psychologically attached to the community, they are more likely to behave in terms of their community values. Therefore, once an individual participate a Social Media brand community and become a fan of this brand page, no matter passive or active mode, he/she would be affected by the community value and gradually develop individual's identification with this brand community. The hypothesis is proposed:

H3 Higher levels of individual community participation would lead to higher levels of individual community identification. 


\section{WOM and repurchase intention}

Post-purchase intentions have been normally employed as a foundation for predicting consumers' future behaviors [55]. It can be defined as customers' intentions to repurchase products or services from the same retailer as well as spread their experience of buying and using the product or service to their friends [56-58]. According to Smith et al. [15], post-purchase intentions can be classified into social behavioral intentions and economic behavioral intentions. Social behavioral intentions refer to cognitive reactions of customers to the delivery of services for service providers, such as word-ofmouth communication intentions [17-19]. While economic behavioral intentions refer to customers' behavioral reactions in the financial aspect, such as repurchase intention [16-19].

Many scholars have confirmed that WOM is a significant post-purchase behavior, as it influences consumers' product and service choices (e.g. [59, 60]). From the study on Zara case, Royo-Vela and Casamassima [12] have demonstrated that the higher the level of participation in a virtual brand community, the higher the positive word-of-mouth advertising towards the brand around which the community is developed. Chuang and Chen [61] also did a research on the relationship between virtual customer participations and WOM. Additionally, members with high identification are more prone to contribute the organization with several desirable cooperative behaviors of helping other members and spreading good references $[14,45,53,62]$. As such, when customers identify themselves with the organization's vision and value, they are interested in the growth of the organization. Consequently, they express positive behaviors such as encouraging word-of-mouth $[63,64]$. Hence, based on the above discussion, the following hypothesis is put forward:

H4 Individual community participation positively affects WOM.

H5 Individual community identification positively affects WOM.

Repurchase intention has been generally defined and broadly examined in social psychology and marketing. In social exchange theory [65], repurchase intention is explained as relationship maintenance. Alternatively, studies in marketing or in organizational behavior conceptualize repurchase intention in terms of an intention to keep the relationship [66]. A research about the brand fan-page from Jahn and Kunz [67] revealed that high usage intensity, get in regular contact with the brand, which in turn should have an effect on their brand relationship and should increase their likelihood for repurchase or word-of-mouth. As such, higher levels of individual participation in a Social Media brand community lead to higher levels of repurchase intention towards the brand. Furthermore, Kuo and Wu [56] mentioned that repurchase intention is an expression of customer loyalty. When consumers identify with a particular community, they become emotionally attached to this community and result in a loyalty intention towards this brand and even increased relative immunity to negative publicity [68]. Besides, Ahearne et al. [69] and Algesheimer et al. [8] pointed out that community identification can cause both extra-role behavior and in-role behavior (e.g. including sustained long-term preference for a particular brand through repeated purchases). 
H6 Individual community participation positively affects repurchase intentions.

H7 Individual community identification positively affects repurchase intentions.

In summary, the integrated theoretical framework as represented by $\mathrm{H} 1-\mathrm{H} 7$ is shown in Figure 1.

\section{Research methodology}

\section{Samples}

The data used to examine the hypotheses were collected from Facebook brand fan-page fans in Taiwan. According to Zhao [70], Facebook brand fan-pages in Taiwan comprise four types: fan-pages for public celebrities, fan-pages for individual sharing, fan-pages for on-line game or app software, and fan-pages for brands or companies. In the top 100 Taiwanese fan-pages in 2011, brand/company fan-pages, e.g. 7-eleven, Starbucks, and Rakuten Ichiba Taiwan, had a 33\% share, [71]. The purpose of this research is to study how individual customer relationship with brand, product, company and other customers in Facebook brand community affects post-purchase intentions; thus, only the fan-page for brands or companies are considered in this study. Moreover, the sample of respondents was obtained based on the following qualifications: (1) respondents should be members of Facebook; (2) respondents should have been registered and active in at least one brand fan page for over 3 months. According to Hair et al. [72], the ratio of observations to the independent variable should not fall below five (5:1). Chin and Newsted [73] suggest that a sample size of 150-200 is needed to attain reliable coefficient values using partial least squares (PLS) analysis [64]. Hence, bearing in mind the 24 variables to be used in SEM, this study requires a minimum sample size of 150 respondents.

\section{Data collection method}

Data were collected in October 2014 via a structured questionnaire developed for the study, adapting those used in previous studies. As the target population in this study consists of people who are members of Social Media brand fan-pages, the Chinese questionnaire was distributed through several posts in social networking sites, such as Facebook and PTT (the local social networking websites in Taiwan with the largest scales

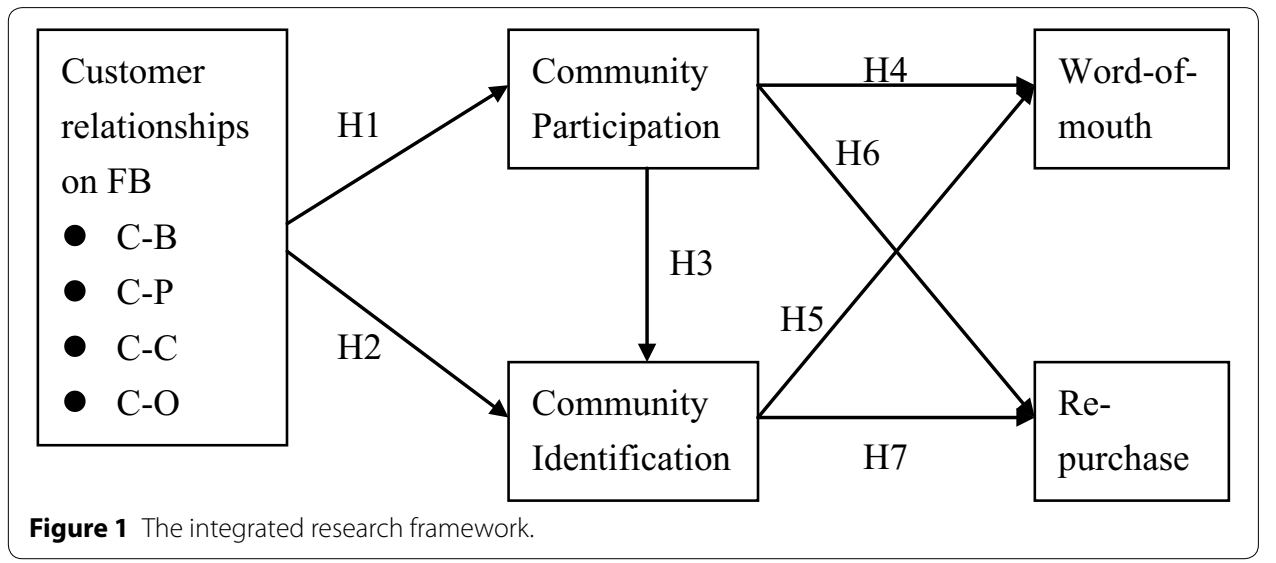


and longest histories). The function of "Ask Question" in Facebook was used to distribute questionnaire and collect data. We asked participants to keep in mind the Facebook brand fan-page of which they were members and followed while answering the questions. Participants were guaranteed confidentiality and anonymity in relation to their returned questionnaires. Self-administered questionnaires with the assistance of a support letter were applied to ensure a good response rate and reduce non-sampling bias throughout the survey process. An effort was made to randomize data collection at different times of the day and week. At the end of the data collection period, a total of 230 questionnaires were collected with 14 ineffective surveys (e.g. unfinished questionnaires and ticking the same answer for all the questions). That is to say, 216 fully completed questionnaires were used for the data analysis.

\section{Measurement of variables}

The survey questionnaire was developed by adapting measurements from a variety of studies. The fan-brand relationship was measured through three items adapted from Fournier [74] and Laroche et al. [36] and the fan-product relationship was measured through three items adapted from Laroche et al. [36] and McQuarrie and Munson [75]. To measure the fan-company relationship, we used the three-item scale proposed by Bhattacharya and Sen [39] and Laroche et al. [36], and to measure fan-other fans relationships, we used the three-item scale proposed by Laroche et al. [36]. Individual community participation was measured using three items adapted from Algesheimer et al. [8] and Qu and Lee [14]. The construct of individual community identification consisted of three items adapted from the works of Bergami and Bagozzi [38] and Qu and Lee [14]. The measures for word-of-mouth construct consisted of three items adapted from Hur et al. [64] and Jahn and Kunz [67]. Post-purchase intentions were also measured using three items adapted from Hur et al. [64] and Jahn and Kunz [67]. All items for assessing the constructs employed a seven-point Likert scale indicating the extent of agreement or disagreement with the item. The items for each construct and their measurement scales are presented in Table 1.

\section{Data analysis}

This study used partial least squares (PLS) and SPSS to test the hypotheses and analyze the data. The PLS algorithm allows each indicator to vary in terms of how much it contributes to the composite score of the latent variable, instead of assuming equal weight for all indicators of a scale [64, 76]. According to Anderson and Swaminathan [77], PLS path modeling is commonly used in marketing [78] international business [79] and information systems $[80,81]$ studies, necessitating simultaneous estimation of the factor loadings of the measurement model and path coefficients of the structural model. This study used PLS rather than other SEM methods (i.e. LISREL or AMOS), because the PLS approach places minimal restrictions on sample size and residual distribution $[64,82]$.

\section{Results}

\section{Demographic profile of respondents}

Of the 216 respondents, $44.2 \%$ were male while $55.8 \%$ were female. In terms of age, $54.4 \%$ were $20-30$ years old, and $28.6 \%$ were under 20 , these two groups accounting for 
Table 1 Constructs and their measurement items

\begin{tabular}{|c|c|c|c|c|c|}
\hline Construct & Measurement items & Loading & $\alpha$ & CR & AVE \\
\hline \multirow[t]{3}{*}{ Customer-Brand relationship } & $\begin{array}{l}\text { This brand is accounted an important } \\
\text { position in my mind }\end{array}$ & 0.86 & 0.77 & 0.87 & 0.68 \\
\hline & I value the heritage of the brand & 0.85 & & & \\
\hline & $\begin{array}{l}\text { I have certain degree of knowledge about } \\
\text { this brand }\end{array}$ & 0.77 & & & \\
\hline \multirow[t]{3}{*}{ Customer-Product relationship } & I am proud of this product & 0.83 & 0.81 & 0.89 & 0.72 \\
\hline & This product is important to me & 0.89 & & & \\
\hline & $\begin{array}{l}\text { I would gather the information related to } \\
\text { this product }\end{array}$ & 0.83 & & & \\
\hline \multirow[t]{3}{*}{ Customer-Company relationship } & I believe this company & 0.89 & 0.91 & 0.94 & 0.84 \\
\hline & The company understands my needs & 0.97 & & & \\
\hline & The company cares about my opinions & 0.96 & & & \\
\hline \multirow[t]{3}{*}{$\begin{array}{l}\text { Customer-Other } \\
\text { customers relationship }\end{array}$} & $\begin{array}{l}\text { I have met wonderful people because of } \\
\text { the community }\end{array}$ & 0.92 & 0.93 & 0.96 & 0.88 \\
\hline & $\begin{array}{l}\text { I have a feeling of kinship with the other } \\
\text { owners }\end{array}$ & 0.89 & & & \\
\hline & $\begin{array}{l}\text { I have an interest in the community } \\
\text { because of the other owners of the } \\
\text { brand }\end{array}$ & 0.94 & & & \\
\hline \multirow[t]{3}{*}{$\begin{array}{l}\text { Individual community } \\
\text { participation }\end{array}$} & $\begin{array}{l}\text { I often watch the brand community } \\
\text { activities }\end{array}$ & 0.84 & 0.74 & 0.85 & 0.66 \\
\hline & $\begin{array}{l}\text { I'm willing to participate this community } \\
\text { because of informational benefits }\end{array}$ & 0.89 & & & \\
\hline & $\begin{array}{l}\text { I'm willing to participate this community } \\
\text { because of social benefits }\end{array}$ & 0.83 & & & \\
\hline \multirow{3}{*}{$\begin{array}{l}\text { Individual community } \\
\text { identification }\end{array}$} & I feel strong ties to other members & 0.88 & 0.89 & 0.93 & 0.82 \\
\hline & $\begin{array}{l}\text { I find it easy to form a bond with other } \\
\text { members }\end{array}$ & 0.92 & & & \\
\hline & $\begin{array}{l}\text { I feel emotionally attached to this com- } \\
\text { munity }\end{array}$ & 0.92 & & & \\
\hline \multirow[t]{3}{*}{ Word-of-mouth } & I often tell others about this brand & 0.87 & 0.79 & 0.88 & 0.71 \\
\hline & I recommend this brand to others & 0.83 & & & \\
\hline & $\begin{array}{l}\text { I will leave positive comments about this } \\
\text { brand on community sites }\end{array}$ & 0.81 & & & \\
\hline \multirow[t]{3}{*}{ Re-purchase intention } & I will repurchase this brand in the future & 0.73 & 0.68 & 0.82 & 0.60 \\
\hline & $\begin{array}{l}\text { I would love to use/support this brand } \\
\text { continuously }\end{array}$ & 0.73 & & & \\
\hline & $\begin{array}{l}\text { I think of myself as a loyal consumer/sup- } \\
\text { porter of this brand }\end{array}$ & 0.86 & & & \\
\hline
\end{tabular}

the largest portion of the sample, followed by those aged 31-40 years (8.3\%). The majority of the respondents (50.0\%) had been members of the fan page for less than 6 months, $21.8 \%$ for less than 1 year, $19.4 \%$ for $1-2$ years, and $8.7 \%$ for over 2 years.

\section{Measurement model}

We used the two-step approach as described by Anderson and Gerbing [83]. Firstly, we assessed reliability and convergent validity as shown in Table 1 , and secondly, discriminant validity, as illustrated in Table 2 . To examine reliability, Cronbach's alpha revealed that all constructs showed a value above 0.6 (the bar adopted by Bagozzi and Yi [84]). To test for convergent validity, composite reliability (CR), factor loading, and average 
Table 2 Correlation matrix

\begin{tabular}{lllllllll}
\hline & C-B & C-P & C-C & C-O & CP & Cl & Wom & RP \\
\hline C-B & 0.82 & & & & & & \\
C-P & 0.67 & 0.85 & & & & & \\
C-C & 0.63 & 0.60 & 0.92 & & & & \\
C-O & 0.33 & 0.41 & 0.22 & 0.94 & & & \\
CP & 0.51 & 0.45 & 0.39 & 0.38 & 0.81 & & \\
Cl & 0.50 & 0.60 & 0.46 & 0.59 & 0.52 & 0.91 & \\
Wom & 0.64 & 0.68 & 0.74 & 0.36 & 0.44 & 0.62 & 0.84 & \\
RP & 0.58 & 0.67 & 0.56 & 0.46 & 0.49 & 0.62 & 0.73 & 0.77 \\
\hline
\end{tabular}

Diagonals represent the square root of the average variance extracted while the other entries represent the correlations.

variance extracted (AVE) were examined. The measures are acceptable if an individual item loading is greater than 0.7 , CR exceeds 0.7 and AVE is greater than 0.5 [85].

In order to examine the discriminant validity of the constructs, this study used the Fornell and Lacker [86] criterion whereby the average variance shared between each construct and its measures should be greater than the variance shared between the construct and other constructs. As shown in Table 2, the correlations for each construct are less than the square root of AVE for the indicators measuring that construct indicating adequate discriminant validity.

\section{Structural model}

The relationship of customer-brand (H1a, $\beta=0.318, \mathrm{p}<0.01)$ and customer/other customers (H1d, $\beta=0.218, \mathrm{p}<0.01$ ) both had a significant and positive influence on community participation, while the customer-product ( $\mathrm{H} 1 \mathrm{~b})$ and the customer-company (H1c) relationship had no significant influence on community participation. Therefore, $\mathrm{H} 1$ is partial supported. Meanwhile, The relationship of customer-product (H2b, $\beta=0.269, \mathrm{p}<0.01)$, customer-company $(\mathrm{H} 2 \mathrm{c}, \beta=0.129, \mathrm{p}<0.1)$ and customer/other customers ( $\mathrm{H} 2 \mathrm{~d}, \beta=0.370, \mathrm{p}<0.01)$ all had a significant and positive influence on community identification, while the customer-brand (H2a) relationship had no significant influence on community identification. Therefore, $\mathrm{H} 2$ gains partial supported as well.

Individual community participation exerted a significant and positive influence on individual community identification $(\mathrm{H} 3, \beta=0.200, \mathrm{p}<0.01)$. Additionally, the paths from community participation $(\mathrm{H} 4, \beta=0.164, \mathrm{p}<0.1)$ and identification $(\mathrm{H} 5, \beta=0.539$, $\mathrm{p}<0.01$ ) both had a significant and positive influence on word-of-mouth. Also the paths from community participation $(\mathrm{H} 6, \beta=0.229, \mathrm{p}<0.01)$ and identification (H7, $\beta=0.501, \mathrm{p}<0.01)$ to re-purchase intentions both showed a significant and positive effect. Thus, H3-H7 is supported. The result shown below in Figure 2.

\section{Discussions and conclusions}

The purpose of this study was to demonstrate how to manage digital customer relationships (i.e. relationships with the brand, the product, the company, and other fans) on social media based community (i.e. Facebook brand fan-pages) and to influence postpurchase intentions (i.e. word-of-mouth and re-purchase intentions). It was concluded that all these four customer-community relationships can enhance post-purchase 


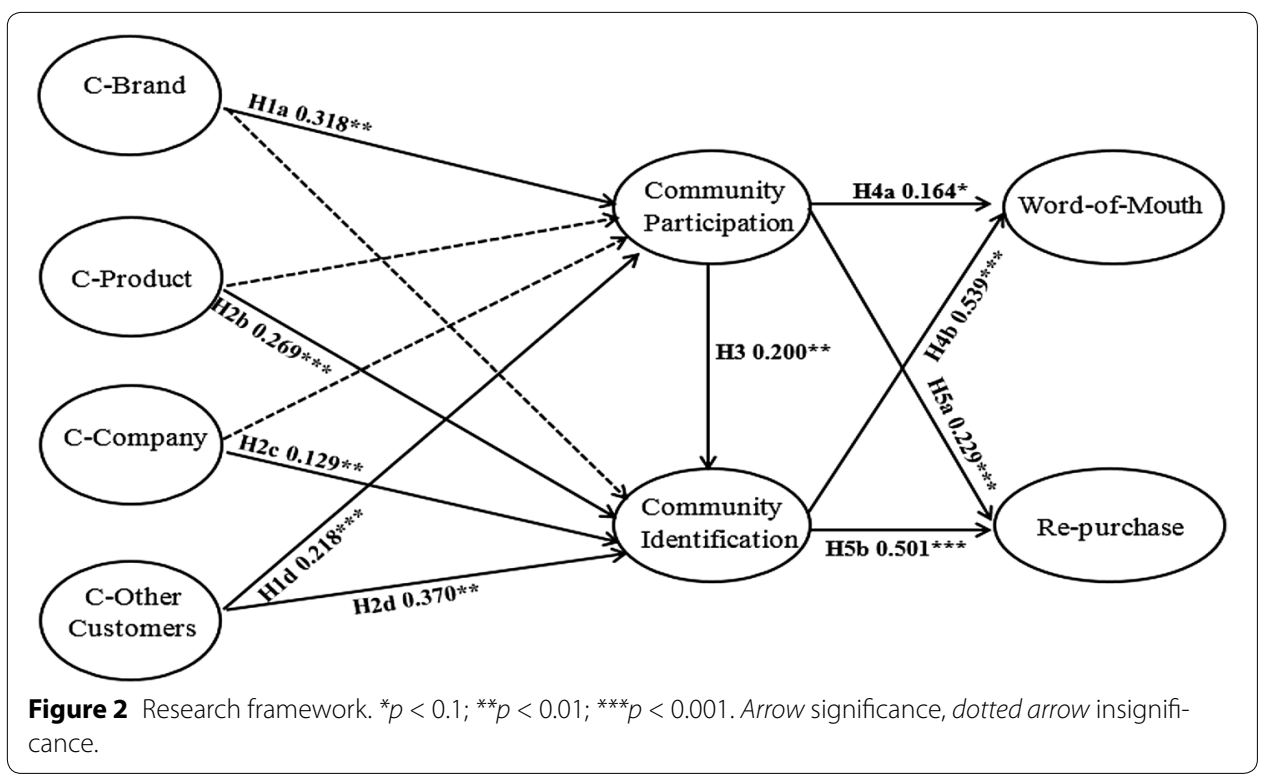

behaviors by improving individual community participation or identification. The results gained from this study offer important contributions and implications for both electronic commerce academia and practitioners.

\section{Theoretical implications}

First, an observation from four digital customer relationships within Social Media brand community in this model, two of them (relationships with the brand and other customers) were positive and significant effects on individual community participation and three of them (relationships with the product, company and other customers) were positive and significant effects on individual community identification. Among these four, only the relationship with other customers gained the significant and positive effect on both individual community participation and identification. This finding shows that the main characteristic of social media is user-generated content and confirms that the focal purpose of the internet-based brand community, e.g. Facebook brand fan-pages, is to bring people together and to facilitate interactions among them. It is consistent with Fournier and Avery [87] and Laroche's et al. [36] research on brand communities in social media.

Second, this study reveals that the customer-brand relationship should have indirect significant effect on individual community identification through the role of community participation as an antecedent of community identity. This finding seems to be different from that of previous literatures, e.g. Fournier et al. [43] and Muniz and Schau [5], but it in some ways is consistent with Chuang's [88] research on car clubs in Taiwan that found that the greater the individual participation in a brand community would help the customer-brand relationship to be strong enough to achieve the greater community identification. Another possible reason could be that almost many brand community on Social Media fan-pages in Taiwan are (or look like) unofficial and the identity or the image of the brand is weak or unclear. Therefore, the influence on identification is insignificant. 
Meanwhile, this study discloses that the customer-product and customer-company relationship within a brand community did not affect community participation but had direct effect on community identification. It shows two possible reasons, firstly, there are less public activities or shared information related to products and the company involved in the Social Media brand fan-pages for fans to participate, interact or discuss. Secondly, "products" and "the company" is more concrete and tangible for fans to realize and identify their relationships than "brand", so they could have direct sense of identification on its Social Media community without doing some participating or interacting activities. Conversely, the relationship with "brand" is conceptual and intangible, so it needs some physical activities as the community participation to help develop the community identification.

Third, in previous studies, the issue of marketing/selling and branding activities on social media based community has been the subject of little systematic research with clear empirical results [36]. This study proposed an exclusive model of the process by which individual customer participation can affect word-of-mouth (including both online and offline) and re-purchase intentions. We have tested and validated this model and found support for the hypotheses in the context of social networking sites. The findings are in some ways consistent with other studies that found that participation in social virtual communities positively influences the loyalty $[36,89]$.

\section{Managerial implications}

The findings in this study have practical implications for electronic commerce practices. First, it is clear that digital customer relationships with brand, product, and other fans in Social Media brand community were positive and significant effects on individual community participation and identification. Accordingly, marketing or e-commerce managers recognizing the important role of different customer relationships within Social Media brand community should make every effort to engage in active management of these digital relationships on Social Media.

Second, currently, even there are some authorized brand fan-pages by companies or brand players on Social Media; they almost look like unofficial and less perception or image of brand. Social Media fans hardly recognize and identify the brand community that is related to this brand. Therefore, practitioners should enhance the brand-community connection and improve customers' perception and identification with this brand in its Social Media brand community.

Third, this study suggests practitioners to pay attention on digital customers' online participation or engagement on Social Media brand community. This is a direct effect between participation/engagement and both social behavioral intention and economic behavioral intention. It not only positive affects on-line behavioral intentions, but also on-line and offline word-of-mouth exchange. In addition, digital customers' community identification is another powerful influence on post-purchase intentions, particularly when the community fans have good affiliations with the brand, product and other fans. Electronic commerce managers should help fan-page members to develop an emotional bond with the brand community. Sustained efforts to give these fans pleasure and enjoyment, and ensure that they have a close attachment to the fan-page will increase their individual identification of the brand community. 
Fourth, this study helps practitioners in their involvement with Facebook brand fanpages. The popularity of Facebook and the vast potential reach, being in no fixed location and low cost, motivates electronic commerce marketers to try to use it in different ways. The model and findings in this study confirm that by managing the interpersonal bonds among digital customer relationships on social networking, and by strengthening customers' community participation and identification, electronic commerce marketers can positively increase post-purchase intentions toward products or brands.

\section{Limitations and future research}

The following limitations of this study should be addressed. When addressing these limitations, we also suggest directions for future research. First, this study adopted community identification as antecedents of post-purchase. Other relational variables, such as brand community commitment, could also be considered and examined as antecedents. Second, our sample comprised primarily young adults (under 30 years old); hence, their responses may not be completely generalizable to the population at large. Thirdly, although the web survey could avoid the regional limitation, the questionnaire in Chinese could limit this study in the Chinese region. Future research could try to translate the questionnaire into English in order to reach more participants from different regions. Finally, this study examined digital customer participation on a specific form of social media based brand community, namely Facebook, so the results could not be ascribed to other formats of internet-based platform. Future researchers could explore consumers' online engagement with regard to different types of e-commerce or m-commerce applications with specific brand or product settings. In the context of other format of internet-based platform, there are so many social networking sites, and virtual communities, stated by eBizMBA Inc. [90]; and the research also listed top 15 most popular social networking sites ranked by Alexa Global Traffic Rank. Moreover, Instagram is the fastest-growing social media site globally, mentioned by Lunden [91]. Therefore, for the further research, the author suggested which could extend the research from Instagram user communities.

Authors' contributions

All authors contributed to the content of this paper. All authors read and approved the final manuscript.

Acknowledgements

On behalf of the research team, Dr. Ching-Wei Ho and I, we would like to thank the reviewers for their valuable comments.

Compliance with ethical guidelines

Competing interests

The authors declare that they have no competing interests.

Received: 22 February 2015 Accepted: 5 July 2015

Published online: 15 July 2015

References

1. Trusov M, Bucklin RE, Pauwels K (2009) Effects of word-of-mouth versus traditional marketing: findings from an internet social networking site. J Mark 73(5):90-102

2. Zarella D (2010) The social media marketing book. O'Reilly Media Inc, Sebastapol

3. Pon YP, Wang CJ (2012) Which keyword let brand control the digital trend? Brand News. http://www.brain.com.tw/ News/RealNewsContent.aspx?ID=17819. Accessed 6 Nov 2012 
4. McAlexander JH, Schouten JW, Koenig HF (2002) Building brand community. J Mark 66(January):38-54

5. Muniz AM Jr, Schau HJ (2005) Religiosity in the abandoned apple Newton brand community. J Consum Res 31(4):737-747

6. Brown S, Kozinets RV, Sherry JF Jr (2003) Teaching old brands new tricks: retro branding and the revival of brand meaning. J Mark 67(July):19-33

7. Franke N, Shah SK (2003) How communities support innovative activities: an exploration of assistance and sharing among end-users. Res Policy 32(January):157-178

8. Algesheimer R, Dholakia UM, Herrmann A (2005) The social influence of brand community: evidence from European car clubs. J Mark 69(July):19-34

9. Lang B (2010) Ipsos OTX study: people spend more than half their day consuming media. The Wrap, September 20. http://www.thewrap.com/media/column-post/people-spend-more-12-day-consuming-media-study-finds-21005/. Accessed 25 July 2014

10. Kaplan AM, Haenlein M (2010) Users of the world, unite! The challenges and opportunities of social media. Bus Horiz 53:59-68

11. Ouwersloot H, Odekerken-Schröder G (2008) Who's who in brand communities- and why? Eur J Mark 42(5/6):571-585

12. Royo-Vela M, Casamassima P (2011) The influence of belonging to virtual brand communities on consumers'affective commitment, satisfaction and word-of-mouth advertising The ZARA case. Online Inf Rev 35(4):517-542

13. Casalo LV, Flavian C, Guinaliu M (2007) The impact of participation in virtual brand communities on consumer trust and loyalty. Online Inf Rev 31(6):775-792

14. Qu H, Lee H (2011) Travelers' social identification and membership behaviors in online travel community. Tour Manag 32:1262-1270

15. Smith AK, Bolton RN, Wagner J (1999) A model of customer satisfaction with service encounters involving failure and recovery. J Mark Res 36(3):356-372

16. Anderson EW, Mittal V (2000) Strengthening the satisfaction-profit chain. J Serv Res 3(2):107-120

17. Maxham JG III (2001) Service recovery's influence on consumer satisfaction, positive word-of-mouth, and purchase intentions. J Bus Res 54(1):11-24

18. Maxham JG III, Netemeyer RG (2002) Modeling customer perceptions of complaint handling over time: the effects of perceived justice on satisfaction and intent. J Retail 78(4):239-252

19. Maxham JG III, Netemeyer RG (2003) Firms reap what they sow: the effects of employee shared values and perceived organizational justice on customer evaluations of complaint handling. J Mark 67(1):46-62

20. Boyd D, Ellison N (2007) Social network sites: definition, history, and scholarship. J Comp Mediat Commun 13(1):210-230

21. Cross R, Parker A (2004) The hidden power of social networks. Harvard Business School Press, Boston

22. Kumar KPP, Geethakumari G (2014) Detecting misinformation in online social networks using cognitive psychology. Hum Centric Comp Inf Sci 4:14. doi:10.1186/s13673-014-0014-x

23. Rafiei M, Kardan AA (2015) A novel method for expert finding in online communities based on concept map and PageRank. Hum Centric Comp Inf Sci. doi:10.1186/s13673-015-0030-5

24. Lee JC (2011) Top 5 questions for managing Facebook Fan Pages!", Internet Buzz Research Center. http://www.ibuzz.com.tw/study-1.asp?|D=19. Accessed 1 Dec 2011

25. Hsu YL (2012) Facebook as international eMarketing strategy of Taiwan hotels. Int J Hosp Manag 31(2012):972-980

26. Cova B, Pace S (2006) Brand community of convenience products. New forms of customers empowerment. The case of My Nutella Community. Eur J Mark 40(9/10):1087-1105

27. Muniz MA, O'Guinn CT (2001) Brand community. J Consum Res 27(4):412-432

28. De Vries L, Gensler S, Leeflang PSH (2012) Popularity of brand posts on brand fan pages: an investigating of the effects of social media marketing. J Interact Mark 26:83-91

29. Kozinets RV (1999) E-Tribalized marketing?: the strategic implications of virtual communities of consumption. Eur Manag J 17(3):252-264

30. Bagozzi RP, Dholakia UM (2006) Antecedents and purchase consequences of customer participation in small group brand communities. Int J Res Mark 23(1):45-61

31. Dholakia UM, Durham E (2010) One café chain's Facebook experiment. Harvard Bus Rev 88(3):26

32. Matzler K, Pichler E, Fuller J, Mooradian TA (2011) Personality, person-brand fit, and brand community: an investigation of individuals, brands, and brand community. J Mark Manag 27(9-10):874-890

33. Dholakia UM, Bagozzi RP, Pearo LK (2004) A social influence model of consumer participation in network- and smallgroup-based virtual communities. Int J Res Mark 21(3):241-263

34. Gwinner KP, Gremler DD, Bitner MJ (1998) Relational benefits in services industries: the customer's perspective. J Acad Mark Sci 26(2):101-114

35. Hars A, Ou S (2002) Working for free? Motivations for participating in open-source projects. Int J Electron Commer 6(3):23-37

36. Laroche M, Habibi MR, Richard MO (2013) To be or not to be in social media: how brand loyalty is affected by social media? Int J Inf Manag 33(1):76-82

37. Lembke S, Wilson MG (1998) Putting the team into teamwork: alternative theoretical contributions for contemporary management practice. Hum Relat 51:927-944

38. Bergami M, Bagozzi RP (2000) Self-categorization affective commitment and group self-esteem as distinct aspects of social identity in the organization. Br J Soc Psychol 39:555-557

39. Bhattacharya CB, Sen S (2003) Consumer-company identification: a framework for understanding consumers' relationships with companies. J Mark 67:76-88

40. Bhattacharya CB, Hayagreeva R, Glynn MA (1995) Understanding the bond of identification: an investigation of its correlates among art museum members. J Mark 59:46-57

41. Underwood R, Bond E, Baer R (2001) Building service brands via social identity: lessons from the sports marketplace. J Mark Theor Prac 9:1-14 
42. Huang HC, Chang CW (2007) Building brand community: a study of VW's club. Taiwan Bus Perform J 1(1):1-26

43. Fournier S, Sensiper S, McAlexander JH, Shouten JW (2001) Building brand community on the Harley-Davidson Posse Ride. Harvard Business School Case, Reprint $\mathbf{5 0 1 0 0 9}$

44. Pratt MG (2000) The good, the bad, and the ambivalent: Managing identification among Amway distributors. Adm Sci Q 45:456-493

45. Dutton JE, Dukerich JM, Harquail CV (1994) Organizational images and member identification. Adm Sci Q 39:239-263

46. Mael FA, Ashforth BE (1989) Social identity theory and the organization. Acad Manag Rev 14(1):20-39

47. Bagozzi RP, Dholakia UM (2002) Intentional social action in virtual communities. J Interac Mark 16(2):2-21

48. Carlson BD, Suter TA, Brown TJ (2008) Social versus psychological brand community: the role of psychological sense of brand community. J Bus Res 61(4):284-291

49. Wang Y, Fesenmaier DR (2004) Towards understanding members' general participation in and active contribution to an online travel community. Tour Manag 25(6):709-722

50. Arnett DB, German SD, Hunt SD (2003) The identity salience model of relationship marketing success: the case of nonprofit marketing. J Mark 67(2):89-105

51. Takahashi M, Fujimoto M, Yamasaki N (2003) The active lurker: influence of an in-house online community on its outside environment. Paper presented at the ACM 2003 International Conference on Supporting Group Work, 2003, Sanibel Island, Florida, November 9-12, 2003

52. Thorbjornsen H, Supphellen M, Nysveen H, Pedersen PE (2002) Building brand relationships online: a comparison of two interactive applications. J Interact Mark 16(3):17-34

53. Gruen TW, Summers JO, Acito F (2000) Relationship marketing activities, commitment, and membership behaviors in professional associations. J Mark 64(3):34-49

54. McWilliam G (2000) Building stronger brands through online communities. Sloan Manag Rev 41(3):43-54

55. Kuo BC, Rao A, Lepsien J, Nobre AC (2009) Searching for targets within the spatial layout of visual short-term memory. J Neurosci 29:8032-8038

56. Kuo YF, Wu CM (2011) Satisfaction and post-purchase intentions with service recovery of online shopping websites: perspectives on perceived justice and emotions. Int J Inf Manag 32(2):127-138

57. Wang HC, Pallister JG, Foxall GR (2006) Innovativeness and involvement as determinants of website loyalty: III theoretical and managerial contributions. Technovation 26(12):1374-1383

58. ZeithamI VA, Berry L, Parasuraman A (1996) The behavioral consequences of service quality. J Mark 60(2):31-46

59. Allsop DT, Bassett BR, Hoskins JA (2007) Word-of-mouth research: principles and applications. J Advert Res 47(4):398-411

60. Lii YS, Pant A, Lee M (2012) Balancing the scales: recovering from service failures depends on the psychological distance of consumers. Serv Ind J 32(11):1775-1790

61. Chuang HM, Chen YS (2015) Identifying the value co-creation behavior of virtual customer environments using a hybrid expert-based DANP model in the bicycle industry. Hum Centric Comp Inf Sci. doi:10.1186/s13673-015-0028-z

62. Feng R, Morrison AM (2007) Quality and value network: marketing travel clubs. Ann Tour Res 34(3):588-609

63. Chonko LB (1986) Organizational commitment in the sales force. J Pers Sell Sales Manag 6(3):19-27

64. Hur WM, Ahn KH, Kim M (2011) Building brand loyalty through managing brand community commitment. Manag Decis 49(7):1194-1213

65. Kelly HH, Thibaut JW (1978) Interpersonal relations: a theory of interdependence. Wiley, New York

66. Morgan RM, Hunt SD (1994) The commitment-trust theory of relationship marketing. J Mark 58(3):20-38

67. Jahn B, Kunz W (2012) How to transform consumers into fans of your brand. J Serv Manag 23(3):344-361

68. Tsai HT, Pai P (2012) Positive and negative aspects of online community cultivation: implications for online stores' relationship management. Inf Manag 49:111-117

69. Ahearne M, Bhattacharya CB, Gruen T (2005) Antecedents and consequences of customer-company identification: expanding the role of relationship marketing. J Appl Psychol 90:574-585

70. Zhao DY (2011) The competition among 15 thousand fan pages. Bus Next 2011(10):130-133

71. Zhao DY, Yang HN (2011) 2011 top 100 Facebook fan pages. Bus Next 2011(10):134-135

72. Hair JF, Black WC, Babin BJ, Anderson RE (2010) Multivariate data analysis. Prentice Hall, Upper Saddle River

73. Chin WW, Newsted PR (1999) Structural equation modeling analysis with small samples using partial least squares. In: Hoyle RH (ed) Statistical strategies for small sample research. Sage Publications, Thousand Oaks, pp 307-341

74. Fournier S (1991) A meaning-based framework for the study of consumer object relations. Adv Consum Res $18: 736-742$

75. McQuarrie EF, Munson JM (1992) A revised product involvement inventory: improved usability and validity. Adv Consum Res 19:108-115

76. Chin WW, Marcolin BL, Newsted PR (2003) A partial least squares latent variable modeling approach for measuring interaction effects: results from a Monte Carlo simulation study and an electronic mail emotion/adoption study. Inf Syst Res 14(2):189-217

77. Anderson RE, Swaminathan S (2011) Customer satisfaction and loyalty in e-markets: a PLS path modeling approach. J Mark Theor Pract 19(2):221-234

78. Hennig-Thurau T, Henning V, Sattler H (2007) Consumer file sharing of motion pictures. J Mark 71(4):1-18

79. Henseler J, Ringle CM, Sinkovics RR (2009) The use of partial least squares path modeling in international marketing. Adv Int Mark 20(4):277-320

80. Al-Gahtani SS, Hubona GS, Wang J (2007) Information technology (IT) in Saudi Arabia: culture and the acceptance and use of IT. Inf Manag 44(8):681-691

81. Burton-Jones A, Hubona GS (2006) The mediation of external variables in the technology acceptance model. Inf Manag 43(6):706-717

82. Phang CW, Sutanto J, Kankanhalli A, Li Y, Tan BCY, Teo HH (2006) Senior citizens' acceptance of information systems: a study in the context of e-government services. Eng Manag IEEE Trans 53(4):555-569 
83. Anderson JC, Gerbing DW (1988) Structural equation modeling in practice: a review and recommended two-step approach. Psychol Bull 103(3):411-423

84. Bagozzi RP, Yi Y (1988) On the evaluation of structural equation models. J Acad Mark Sci 16(1):74-94

85. Gefen D, Straub D, Boudreau MC (2000) Structural equation modeling and regression: guidelines for research practice. Commun Assoc Inf Syst 7(7):1-78

86. Fornell C, Lacker DF (1981) Evaluation structural equation models with unobserved variables and measurement error. J Mark Res 18(1):39-50

87. Fournier S, Avery J (2011) The uninvited brand. Bus Horiz 54(3):193-207. doi:10.1016/j.bushor.2011.01.001

88. Chuang BJ (2006) The impacts of four relationships of brand community members on brand community identification and loyalty - the example of automobile community, Master Dissertation, National Cheng Kung University

89. Kardaras D, Karakostas B, Papathanassiou E (2003) The potential of virtual communities in the insurance industry in the UK and Greece. Int J Inf Manag 23(1):41-53

90. ebizMBA Inc. (2015) Top 15 most popular social networking sites, retrieved from http://www.ebizmba.com/articles/ social-networking-websites

91. Lunden I (2014) Instagram is the fastest-growing social site globally, mobile devices rule over pcs for access, retrieved from http://techcrunch.com/2014/01/21/instagram-is-the-fastest-growing-social-site-globally-mobiledevices-rule-over-pcs-for-social-access/. Accessed 25 Jan 2015

\section{Submit your manuscript to a SpringerOpen ${ }^{\circ}$ journal and benefit from:}

- Convenient online submission

- Rigorous peer review

- Immediate publication on acceptance

- Open access: articles freely available online

- High visibility within the field

- Retaining the copyright to your article

Submit your next manuscript at $\boldsymbol{\nabla}$ springeropen.com 